\title{
Gonadotropin and Testosterone Measurements after Estrogen Administration to Adult Men, Prepubertal and Pubertal Boys, and Men with Hypogonadotropism: Evidence for Maturation of Positive Feedback in the Male
}

\author{
HOWARD E. KULIN ${ }^{(26)}$ AND EDWARD O. REITER \\ Reproduction Research Branch, National Institute of Child Health and Human Development, National Institutes of \\ Health, Bethesda, Maryland, USA
}

Extract

Nineteen male subjects were given five daily injections of $17 \beta$-estradiol and circulating levels of estradiol $\left(E_{2}\right)$, testosterone $(\mathbf{T})$, and gonadotropins were determined by radioimmunoassay before, during, and after the steroid course. Peak levels of $\mathbf{E}_{2}$ attained during the 5 days of treatment ranged from $173-577 \mathrm{pg} / \mathrm{ml}$. Four of seven normal adult men and one castrate man demonstrated suppression of follicle-stimulating hormone ( $\mathrm{FSH})$ and luteinizing hormone ( $\mathbf{L H}$ ) with a subsequent rise in $\mathbf{L H}$ (positive feedback) while $E_{2}$ levels remained elevated. $A$ rise in $T$ was associated with the LH increment in the four normal men. Nine pre-, early, or midpubertal boys and two men with hypogonadotropic hypogonadism displayed only gonadotropin suppression after $E_{2}$ administration. The difference in $\mathrm{LH}$ response to estrogen (i.e., positive feedback) between the adult men with normal or elevated gonadotropin levels as compared with the endocrinologically normal boys is significant $(P<\mathbf{0 . 0 1})$.

\section{Speculation}

Positive feedback between estrogen and $\mathrm{L} . \mathrm{H}$ is present in intact adult men, although the magnitude and consistency of this response is less than in women. Testosterone in men may act like progesterone in the female rhesus monkey to blunt the magnitude of the $\mathbf{L H}$ rise during estrogen administration. The potential for positive feedback appears to be a maturational event occurring during puberty in men as well as in women.

Sexual differentiation of the brain and the consequent ability of the female of the species to exhibit regular ovulatory cycles exists in certain rodents and can be influenced by neonatal exposure to a number of steroid hormones. In contrast, fetal and neonatal exposure of the brain of the rhesus monkey to gonadal steroids does not appear to influence the basic hypothalamic mechanisms controlling reproduction (4).

The ability of estrogen to induce the release of $\mathrm{LH}$, termed positive feedback, has been demonstrated in the intact, adult female and in the postpubertal, castrate male, and female rhesus monkey (18). Such effects of estrogen have not been found in the intact, adult male rhesus. LH release after estrogen administration has also been demonstrated in adult women $(9,11)$ but not in sexually immature girls (11). The onset of positive feedback appears to be a late pubertal event in the female (11). We should like to present evidence that a stimulatory luteinizing hormone response to exogenous estrogen is also a maturational event in men.

\section{MATERIALS AND METHODS}

\section{SUBJECTS}

Seven normal, adult men (ages 20-22) and one male (age 21) with the syndrome of vanishing testes (1) were hospitalized for study at the Clinical Center of the National Institutes of Health. Each patient was given five daily intramuscular injections of 10 or $15 \mu \mathrm{g} / \mathrm{kg}$ body weight of $17 \beta$-estradiol $\left(E_{2}\right)(20)$ and blood samples were obtained every $12-24 \mathrm{hr}$ before, during, and after the estrogen course (see Table 1).

Nine endocrinologically normal boys between the ages of 7 and 18 were studied in the course of evaluation for short stature, precocious puberty, or delayed adolescence. Seven of the nine boys received $E_{2}$ injections at a dose of 10 or $15 \mu \mathrm{g} / \mathrm{kg}$ body weight for 5 days in a fashion similar to the adult men. Two prepubertal patients received five daily injections at a dose of 1 to $3 \mu \mathrm{g} / \mathrm{kg}$ body weight, although the plasma levels of estradiol obtained were similar to those measured in subjects who received a larger amount of steroid.

Two men, ages 20 and 23, with hypogonadotropic hypogonadism were also given the 5-day regimen of estradiol injections at a dose of $15 \mu \mathrm{g} / \mathrm{kg}$ body weight $/ 24 \mathrm{hr}$. Blood samples in the pre-, early, and midpubertal subjects were also obtained every $12-24 \mathrm{hr}$ before, during, and after administration of estrogen (Figs. 4-6). Informed consent was obtained from each subject and/or his parents.

\section{ASSAYS}

Plasma FSH and $\mathrm{LH}$ were measured by radioimmunoassay (10), using the Second International Reference Preparation of Human Menopausal Gonadotropin (2nd IRP hMG) as standard material for dose interpolation. In our laboratory $1 \mathrm{mIU}$ of plasma FSH and LH activity of 2nd IRP hMG is immunoreactively equivalent to $30 \mathrm{ng}$ and $3.9 \mathrm{ng}$, respectively, of the pituitary standard LER-907. Samples were assayed at multiple dilutions in volumes between 50 and $300 \mu \mathrm{l}$, with the sensitivity limits of the radioimmunoassay being approximately $0.5 \mathrm{mIU} /$ assay tube for both FSH and LH. The intra- and interassay coefficients of variation, respectively, for FSH and LH were approximately $10 \%$ and $20 \%$.

$E_{2}$ was measured by a radioimmunoassay (8) with a sensitivity of approximately $5 \mathrm{pg} /$ assay tube and intra- and interassay coefficients of variation of $11 \%$ and $15 \%$. T was also determined by a radioimmunoassay (3), with a sensitivity of approximately 10 $\mathrm{pg} /$ assay tube and intra- and interassay coefficients of variation of $8 \%$ and $12 \%$. All samples from a given patient were analyzed in the 
Table 1. Data from four men who displayed suppression and subsequent luteinizing hormone $(L H)$ elevation with estrogen

\begin{tabular}{|c|c|c|c|c|c|c|c|c|c|c|c|c|c|c|}
\hline \multicolumn{2}{|c|}{ Study } & \multirow[b]{2}{*}{$\begin{array}{l}\text { Treat- } \\
\text { ment }^{1}\end{array}$} & \multicolumn{3}{|c|}{$P H^{2}$} & \multicolumn{3}{|c|}{$J K^{3}$} & \multicolumn{3}{|c|}{$T S^{4}$} & \multicolumn{3}{|c|}{$C W^{5}$} \\
\hline Day & Time & & $\begin{array}{c}\mathrm{LH}, \\
\mathrm{mIU} / \mathrm{ml}\end{array}$ & $\begin{array}{l}\text { Testos- } \\
\text { terone, } \\
\mathrm{ng} / 100 \mathrm{ml}\end{array}$ & $\begin{array}{c}\text { Estra- } \\
\text { diol, } \\
\mathrm{pg} / \mathrm{ml}\end{array}$ & $\begin{array}{c}\mathrm{LH}, \\
\mathrm{mIU} / \mathrm{ml}\end{array}$ & $\begin{array}{l}\text { Testos- } \\
\text { terone, } \\
\mathrm{ng} / 100 \mathrm{ml}\end{array}$ & $\begin{array}{l}\text { Estra- } \\
\text { diol, } \\
\mathrm{pg} / \mathrm{ml}\end{array}$ & $\begin{array}{c}\mathrm{LH}, \\
\mathrm{mIU} / \mathrm{ml}\end{array}$ & $\begin{array}{c}\text { Testos- } \\
\text { terone, } \\
\mathrm{ng} / 100 \mathrm{ml}\end{array}$ & $\begin{array}{l}\text { Estra- } \\
\text { diol, } \\
\mathrm{pg} / \mathrm{ml}\end{array}$ & $\begin{array}{c}\mathrm{LH}, \\
\mathrm{mIU} / \mathrm{ml}\end{array}$ & $\begin{array}{c}\text { Testos- } \\
\text { terone, } \\
\mathrm{ng} / 100 \mathrm{ml}\end{array}$ & $\begin{array}{c}\text { Estra- } \\
\text { diol, } \\
\mathrm{pg} / \mathrm{ml}\end{array}$ \\
\hline \multirow[t]{2}{*}{1} & $\mathrm{AM}$ & $C_{1}$ & 9.3 & & & & & & & & & 8.2 & 655 & \\
\hline & PM & & & & & & & & & & & 7.4 & 659 & 36 \\
\hline \multirow[t]{2}{*}{3} & $\mathrm{AM}$ & $\mathrm{C}_{3}$ & 7.8 & & & 12.0 & & & 7.8 & & & 7.6 & 888 & \\
\hline & $\mathrm{PM}$ & & & & & 9.3 & & & 6.8 & & & & & \\
\hline \multirow[t]{2}{*}{4} & $\mathrm{AM}$ & $C_{4}$ & 11.0 & 586 & 39 & 8.5 & 539 & 38 & 11.5 & 324 & 40 & 6.9 & 770 & 53 \\
\hline & PM & & & & & 8.3 & & & 9.5 & & & & & \\
\hline \multirow[t]{2}{*}{5} & $\mathrm{AM}$ & $\mathrm{C}_{5}$ & 10.3 & 610 & 59 & 8.5 & 567 & 31 & 9.5 & 386 & 59 & 10.2 & & \\
\hline & PM & & & & & 6.0 & & & 10.3 & & & & & \\
\hline \multirow[t]{2}{*}{8} & $\mathrm{AM}$ & $E_{3}$ & $4.0(\mathrm{~N})^{6}$ & 474 & 315 & 4.6 & 72 & 216 & 8.8 & 47 & 79 & 2.4 & 295 & 392 \\
\hline & $\mathrm{PM}$ & & & & & $3.2(\mathrm{~N})$ & & & 5.8 & & & & & \\
\hline \multirow[t]{2}{*}{9} & $\mathrm{AM}$ & $E_{4}$ & 6.3 & 398 & 360 & 3.7 & 48 & 279 & $5.5(\mathrm{~N})$ & 68 & 208 & $<1.5(\mathrm{~N})$ & 106 & 412 \\
\hline & PM & & & & & 4.2 & & & 5.8 & & & & & \\
\hline \multirow[t]{2}{*}{10} & $\mathrm{AM}$ & $E_{5}$ & $13.5(\mathrm{P})^{6}$ & 496 & 175 & 4.9 & 62 & 258 & 6.5 & 76 & 268 & $<1.5$ & 79 & 394 \\
\hline & $\mathrm{PM}$ & & & & & 7.5 & & & 8.5 & & & $<1.5$ & 88 & \\
\hline \multirow[t]{2}{*}{11} & $\mathrm{AM}$ & & 10.9 & 670 & 226 & 6.5 & 170 & 577 & 10.8 & 143 & 267 & $5.6(\mathrm{P})$ & 139 & 296 \\
\hline & PM & & & & & $8.8(\mathrm{P})$ & & & 11.3 & & & 1.8 & 103 & 147 \\
\hline \multirow[t]{2}{*}{12} & $\mathrm{AM}$ & & 8.0 & 831 & 139 & 6.8 & 227 & 398 & $12.0(\mathrm{P})$ & 151 & 154 & 2.9 & 216 & 138 \\
\hline & PM & & & & & 6.5 & & & 10.5 & & & & & \\
\hline \multirow[t]{2}{*}{13} & $\mathrm{AM}$ & & 7.8 & 548 & 88 & 4.8 & 90 & 248 & 6.5 & 120 & 195 & 4.1 & 237 & \\
\hline & $\mathrm{PM}$ & & & & & 3.5 & 60 & & 6.8 & 30 & & & & \\
\hline
\end{tabular}

${ }^{1} \mathrm{C}$ : control days, which includes the first day of estrogen injection, denoted as $E_{1}$. Blood samples on the days of estrogen administration ( $E_{1}, E_{2}$, etc.) were drawn before drug administration. Subject $P H$ received $10 \mu \mathrm{g} / \mathrm{kg}$ of estradiol $/ 24 \mathrm{hr}$ while the remaining three subjects received $15 \mu \mathrm{g} / \mathrm{kg} / 24 \mathrm{hr}$ of the steroid.

${ }^{2}$ Patient represented by $\Delta$ in Figure 1 .

${ }^{3}$ Patient represented by $\square$ in Figure 1 .

${ }^{4}$ Patient represented by $O$ in Figure 1.

${ }^{5}$ Patient represented by 0 in Figure 1 .

${ }^{6} \mathrm{~N}$ : nadir; P: peak points utilized to draw Figure 1.

same radioimmunoassay for gonadotropins or steroids. Since estrogen levels were determined from blood samples obtained just before each hormone injection, the $E_{2}$ values reported represent the minimum circulating blood levels.

\section{DATA ANALYSIS}

Because of the asynchronous responses in the group of adult men who displayed an increment in $\mathrm{LH}$ after estradiol administration, the data from each of these four men were aligned on the basis of the $\mathrm{LH}$ peak and the $\mathrm{LH}$ nadir in order that the results could be more easily visualized (Fig. 1). Data were analyzed by the unpaired Student $t$-test and are reported as the mean $(\bar{\chi})$ and SEM. The Fisher Exact Probability Test (16) was used to compare the results from the adult men and the immature boys. Positive feedback was defined arbitrarily as greater than a doubling of LH values from nadir to peak in the presence of continued high estrogen levels such that suppression again occurred after the LH rise; additionally, this effect had to take place well within the limits of assay sensitivity.

\section{RESULTS}

\section{ADULT MEN}

The results from four of the seven normal men who exhibited positive feedback are presented in Figure I and Table I. There was a prompt suppression of gonadotropins and testosterone in the presence of increasing plasma $E_{2}$ levels. Five to 7 days after the initiation of the estrogen course, and still in the presence of elevated $\mathrm{E}_{2}$, there was a significant $(P<0.01)$ mean rise in $\mathrm{LH}$ from the nadir $(3.5 \pm 0.9(\mathrm{SEM}) \mathrm{mIU} / \mathrm{ml})$ back to baseline $(10.0$ $\pm 1.8 \mathrm{~m} \mathrm{IU} / \mathrm{ml}$ ). Since suppressive doses of estrogen eliminate or markedly reduce the circhoral pattern of gonadotropin release in women (19) and men (13), the mean threefold elevation can be considered as an example of positive feedback. The decreasing estrogen levels during the latter part of the study period probably did not play a role in the LH rise, since suppression recurred after the peak. Estrogen levels were similar at peak and nadir times (Table 1) and ranged from peak values of $268-577 \mathrm{pg} / \mathrm{ml}$. These are levels comparable with estrogen determinations obtained during the late follicular phase of the normal female menstrual cycle.

FSH decreased in all four individuals, but the subsequent rise was only slight. A rise and fall in testosterone levels occurred within $24 \mathrm{hr}$ of the $\mathrm{LH}$ perturbations and appear to be related to the changes in the tropic hormone.

A patient with the syndrome of vanishing testes, low circulating testosterone, and castrate levels of gonadotropins was given 15 $\mu \mathrm{g} / \mathrm{kg}$ of $17 \beta$-estradiol daily for 5 days (Fig. 2). In this individual, a marked suppression of gonadotropins took place with a subsequent fivefold rise in LH, from the nadir to levels well above baseline; after this rise, suppression again occurred. Testosterone 


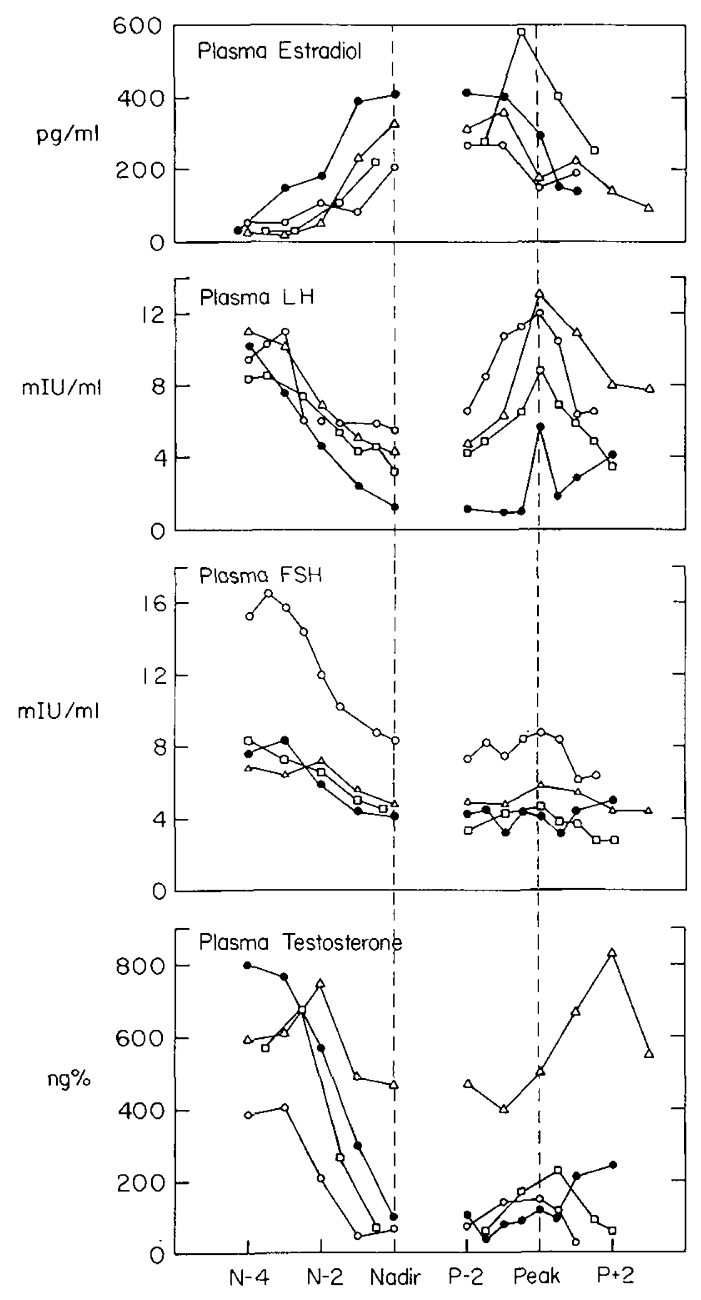

Fig. 1. Four men who exhibited gonadotropin suppression 3-4 days after the initiation of estrogen injections, followed by a luteinizing hormone $(L H)$ rise in the presence of elevated estradiol levels. Because of asynchronous timing, the results from all individuals are aligned on the basis of the nadir and peak LH determinations. The mean nadir time was on day 4 of the estrogen course and the mean peak time occurred on day 6 . The time in days with respect to nadir and peak is shown on the $\mathrm{X}$ axis $(e . g ., N-2$ is 2 days before the nadir point). $F S H$ : follicle-stimulating hormone.

measurements did not change, possibly because of maximal stimulation by $\mathrm{LH}$ throughout the $\mathrm{E}_{2}$ course. The results of the study in this physiologically castrate man are qualitatively similar to those reported by Yamaji et al. (18) in the postpubertal, castrate, male rhesus monkey.

Three of the seven adult men showed only suppression of gonadotropins during and after the $E_{2}$ course (Fig. 3). Testosterone levels also. remained suppressed in these three subjects until $E_{2}$ and/or LH levels had returned towards baseline, suggesting that the $T$ elevations exhibited by the four men whose results are shown in Figure 1 were related to the LH increments.

The peak $E_{2}$ levels during the treatment period were not statistically different between the men who displayed positive feedback and those who did not, although the highest estrogen values were measured in the former group. Basal testosterone measurements were also similar in both groups of men. Basal estrogen levels were less than $60 \mathrm{pg} / \mathrm{ml}$ in all subjects tested in the study.

\section{PREPUBERTAL AND PUBERTAL. BOYS}

Three prepubertal boys, ages 7, 11, and 13 (21), attained peak estradiol levels between 173 and $284 \mathrm{pg} / \mathrm{ml}$ during the 5-day steroid course (Fig. 4). LH and FSH values decreased in all three boys, although the one subject with the lowest LH measurements showed only minimal decrements in this hormone. The small plasma LH increments seen in two of the boys occurred close to the limits of assay detectability and are of dubious significance.

Three early pubertal boys, ages 9,11 , and 14 , attained peak estradiol levels between 181 and $400 \mathrm{pg} / \mathrm{ml}$ during estrogen administration (Fig. 5). Only suppression of gonadotropins took place, although, again, one subject with very low hormone values displayed little apparent LH decrease.

The three midpubertal boys, ages 11,15 , and 18 , who received estrogen had higher basal gonadotropin levels than the younger subjects, as expected (Fig. 6). Additionally, testosterone values were easily measured and showed a prompt suppression, along with the gonadotropins. Peak estradiol values ranged between 183 and $260 \mathrm{pg} / \mathrm{ml}$, similar to the values obtained in the other men and boys who were studied.

The existence of a stimulatory $\mathrm{LH}$ response in five of eight adult men as compared with none of the nine pre-, early, or midpubertal children is a statistically significant difference $(P<0.01)$. If the castrate man is excluded and the four adult respondees (of seven total) are compared with the nine children (no respondees), the $P$ value is $<0.02(16)$.
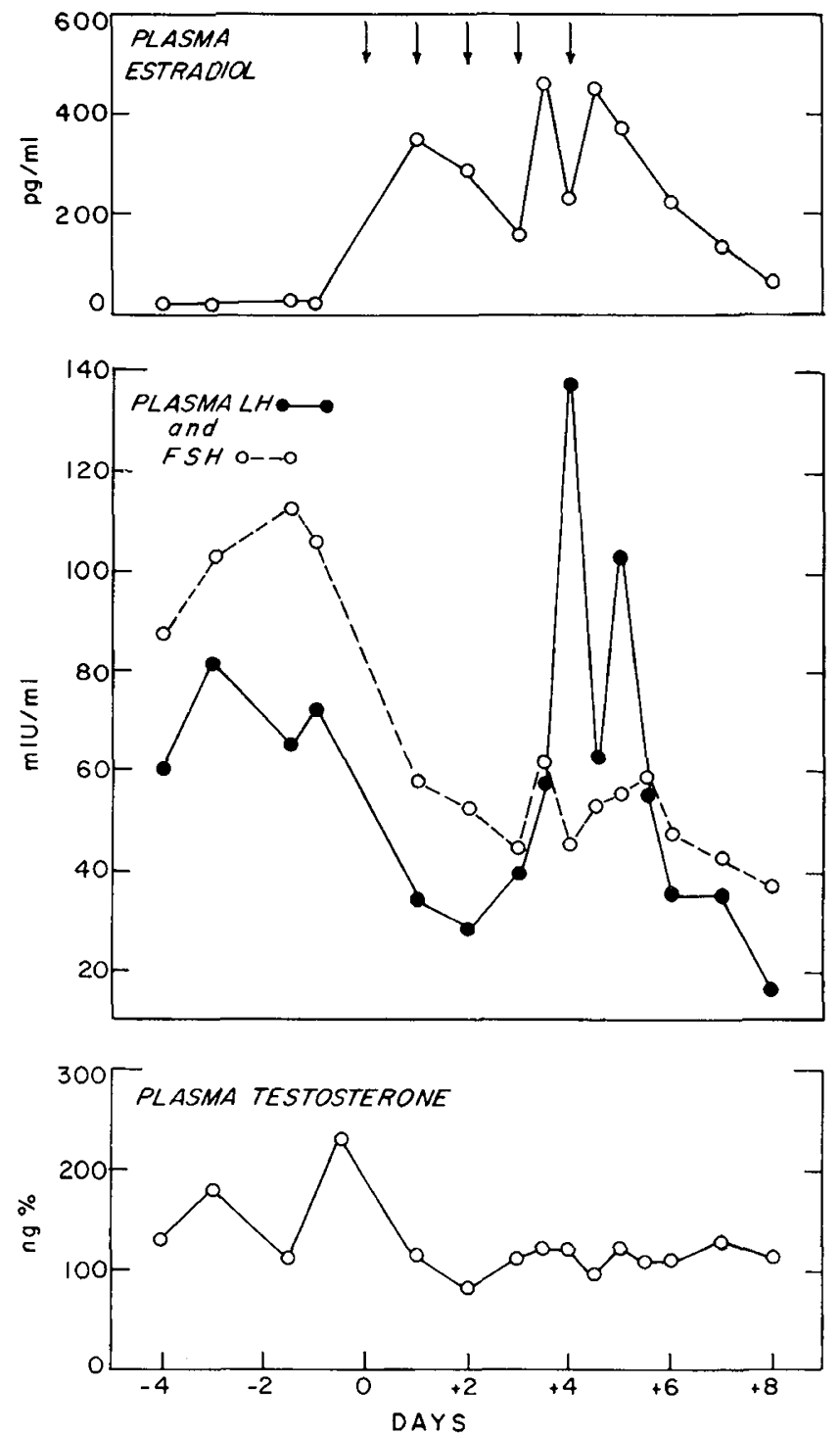

Fig. 2. A 21-year-old patient with elevated gonadotropin and low testostcrone levels who showed a marked rise in luteinizing hormone $(L H)$, after suppression, in the presence of elevated estradiol levels. The arrows indicate the times of estrogen injections. FSH: follicle-stimulating hormone. 

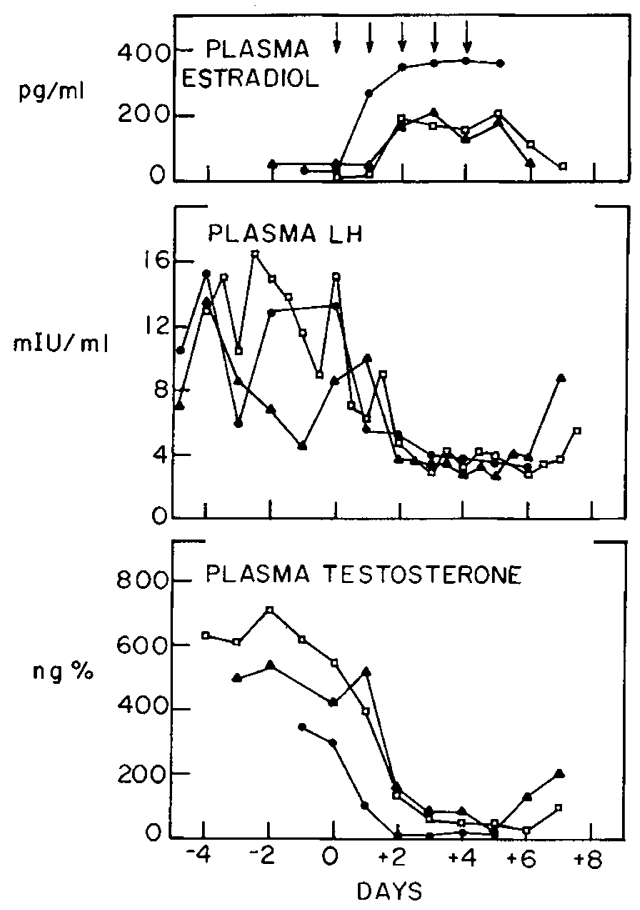

Fig. 3. Three men who received $17 \beta$-estradiol injections, but who showed only suppression of luteinizing hormone $(L H)$, follicle-stimulating hormone (not shown), and testosterone.

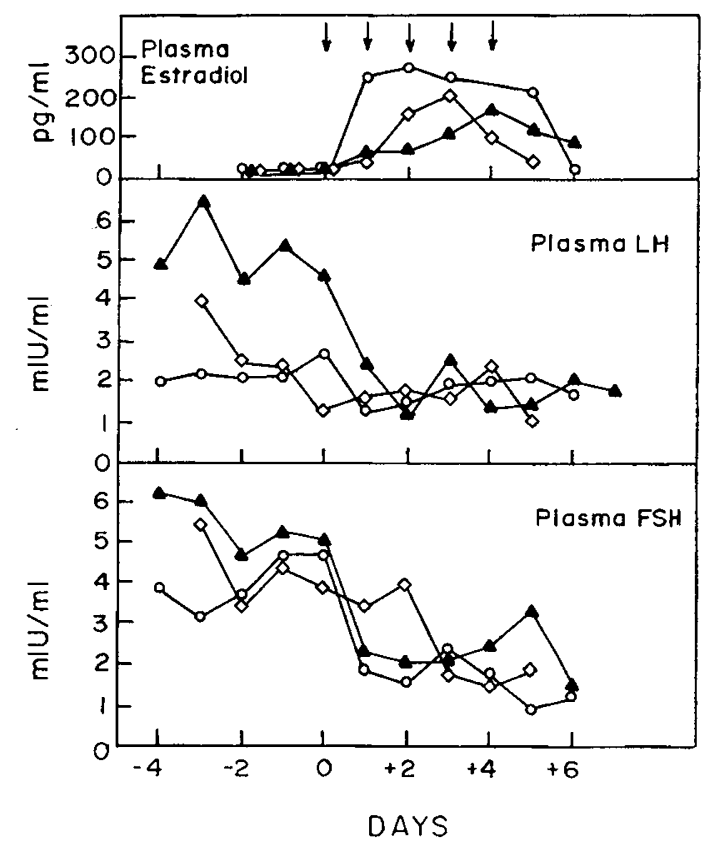

Fig. 4. The effect of $17 \beta$-estradiol administration (denoted by arrows) to three prepubertal boys for 5 days. $L H$ : luteinizing hormone; $F S H$ : follicle-stimulating hormone.

\section{HYPOGONADOTROPIC MEN}

Two men with hypogonadotropic hypogonadism, ages 20 and 23 , were also tested with 5 days of estradiol injections. The results, shown on Figure 7, demonstrated FSH and LH suppression without notable increments, while circulating estradiol remained elevated (between 300 and $400 \mathrm{pg} / \mathrm{ml}$ ).

There were no significant group differences in the peak estrogen levels attained between any of the groups of subjects studied. The only side effects experienced by any of the patients were a mild degree of breast tenderness and/or the appearance of a small nubbin of breast tissue at the end of the study period. These manifestations resolved in all individuals.

\section{DISCUSSION}

The data from five of eight adult men with normal or elevated gonadotropin levels (Fig. I and Table 1) show that the development of a basic central nervous system control mechanism for reproduction, once thought to be unique to the female, may be similar for men and women. Support for such a thesis exists in the study of Stearns et al. (17), who demonstrated a positive feedback effect. of progestins upor. LH in five estrogen-primed, castrate men. Additionally, Seyler and Reichlin (15) have recently presented data which suggests that estrogens may stimulate endogenous luteinizing hormone-releasing factor (LRF) secretion in men.

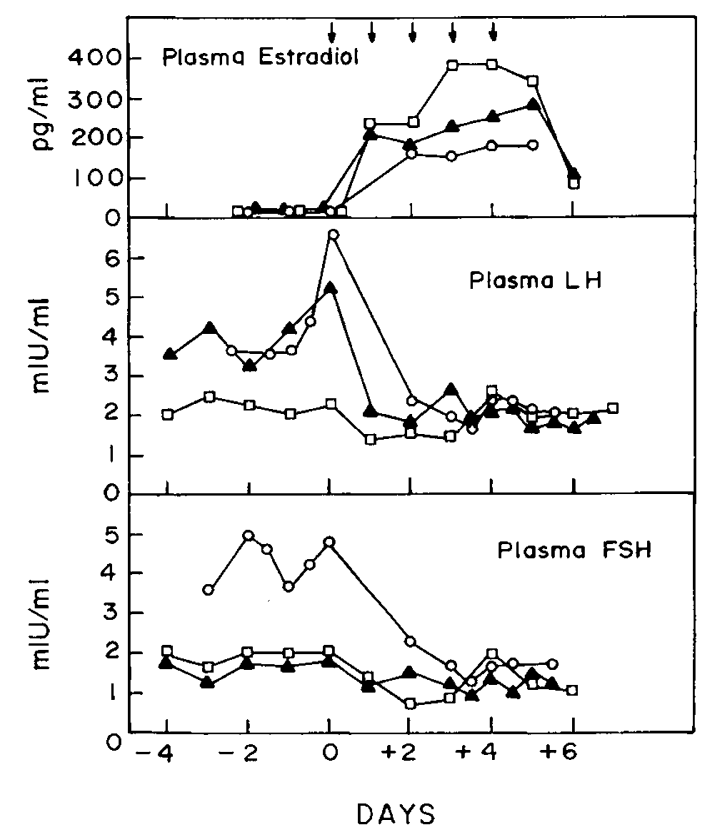

Fig. 5. Results from three early pubertal boys given estradiol protocol. $L H$ : luteinizing hormone; $F S H$ : follicle-stimulating hormone.

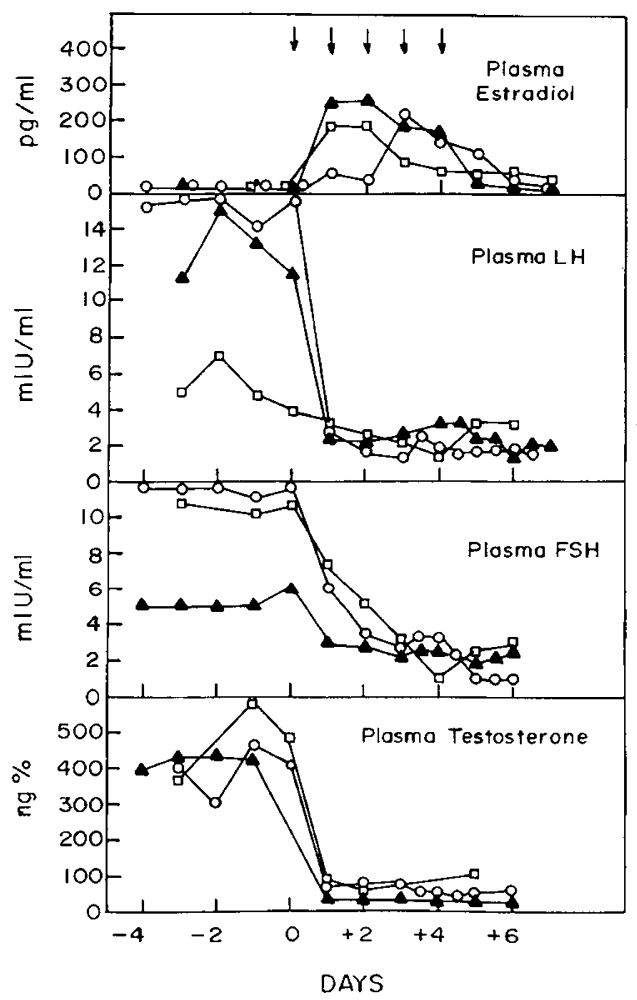

Fig. 6. Three midpubertal boys were given $15 \mu \mathrm{g} / \mathrm{kg}$ of $17 \beta$-estradiol for 5 days. $L H$ : luteinizing hormone; $F S H$ : follicle-stimulating hormone. 


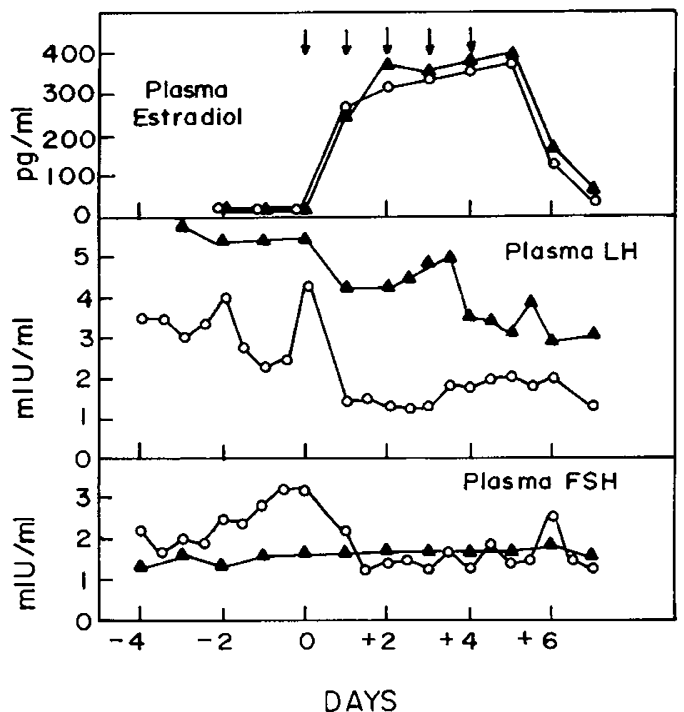

Fig. 7. Hormone measurements in two patients with hypogonadotropism given estrogen injections (arrows) for 5 days. $L H$ : luteinizing hormone; $F S H$ : follicle-stimulating hormone.

Administration of higher doses of estrogen to intact adult men may be necessary to effect a positive feedback response of greater magnitude in all subjects, as testosterone, like progesterone in the female rhesus, may diminish the stimulatory LH effect of $17 \beta$ estradiol (5). Recently, Santen (13) has presented evidence that testosterone in men may have a progesterone-like effect on the nature of the spontaneous LH pulse released by the pituitary gland.

Further evidence for dose-related effects of estrogen in causing an LH surge was provided by Reiter, Kulin, and Hamwood (11). Four adult women who achieved peak $\mathrm{E}_{2}$ levels between 100 and $200 \mathrm{pg} / \mathrm{ml}$ during 5 days of estrogen administration exhibited LH responses very similar to those of the four adult men studied above; in other women, higher levels of $E_{2}$ after a 5-day estrogen course were associated with greater $\mathrm{LH}$ stimulatory responses after initial gonadotropin suppression (11).

The present work suggests a difference between the rhesus monkey and man regarding the ability of estrogen to release $\mathrm{LH}$ in some intact, adult males. Brain mechanisms which control reproductive function between the sexes may differ, then, not only among mammalian orders, but even among primate species. Although the rodent has been a useful animal for investigations in reproductive biology, increasing attention is being focused on the primate for studies in this field (2).

Although only five of eight men with normal or elevated levels of gonadotropins responded to the estrogen protocol with a rise in $\mathrm{LH}$, while estrogen levels remained elevated, none of the nine pre-, early, or midpubertal boys displayed such an effect after the administered steroid. Additionally, two patients with hypogonadotropism exhibited only suppression of FSH and $\mathrm{LH}$, a response similar to the younger subjects. This later finding is consistent with either a specific hypothalamic abnormality in hypogonadotropic hypogonadism, or with a maturation arrest of the normal pubertal process (14).

The high level of significance $(P<0.01)$ between a stimulatory $\mathrm{LH}$ response in five of eight adult men compared with none of nine pre-, early, or midpubertal children suggests that the adult and immature male respond differently to exogenously administered estradiol. This difference may be due to a maturational event in the male similar to the phenomenon which allows positive feedback and consequent ovulation in the female (11).

Whether the maturational aspects of the positive feedback phenomenon resides in the hypothalamus or pituitary or in both sites is unresolved. The onset of puberty is associated with increased LH release after exposure to exogenous LRF, although even the prepubertal child is responsive to this stimulus (12). The fact that none of the six early- or midpubertal boys responded to estrogen with an $\mathbf{L H}$ rise suggests that limited pituitary responsivity to endogenous LRF is not the reason for an absent $\mathrm{LH}$ rise after estrogen administration to the younger subjects. Thus, a hypothalamic locus for the maturation of positive feedback is likely.

The relationship between the development of positive feedback potential in the male to the appearance of a stimulatory gonadotropin response to clomiphene citrate $(6)$ remains unclear. Clomiphene responsivity of the adult type does appear to be a late pubertal event in boys (7), and could be a process which involves both pituitary and hypothalamus.

\section{SUMMARY}

Exogenous estradiol given for 5 days effected initial suppression and then elevation of luteinizing hormone $(\mathrm{LH})$ and testosterone in four of seven normal men and one physiologically castrate man. Nine pre-, early, or midpubertal boys and two adult men with hypogonadotropic hypogonadism exhibited only LH suppression after a similar estrogen course. Positive feedback between estrogen and the hypothalamic pituitary unit exists in men as well as in women, and may be a maturational event in both sexes.

\section{REFERENCES AND NOTES}

1. Aberyaratne, M. R., Aherne, W. A., and Scott, J. E. S.: The vanishing testes. Lancet, ii: 822 (1969).

2. Diczfalusy, E., and Standley, C. C. (eds.): The use of non-human primates in research in human reproduction. Acta Endocrinol. Suppl. 166 (1972).

3. Dufau, M. L., Catt, K. J., Tsuruhara, T., and Ryan, D.: Radioimmunoassay of plasma testosterone. Clin. Chim. Acta, 37: 109 (1972).

4. Karsch, F. J., Dierschke, D. J., and Knobil, E.: Sexual differentiation of pituitary function: Apparent difference between primates and rodents. Science, 179: 484 (1973).

5. Knobil, E.: On the control of gonadotropin secretion in the rhesus monkey Recent Progr. Hormone Res., 30: 1 (1974).

6. Kulin, H. E., Grumbach, M. M., and Kaplan, S. L..: Gonadal-hypothalamic interaction in prepubertal and pubertal man: Effect of clomiphene citrate on urinary follicle-stimulating hormone and luteinizing hormone and plasma testosterone. Pediat. Res., 6: 162 (1972).

7. Kulin, H. E., Reiter, E. O., and Bridson, W. E.: Pubertal maturation of the gonadotropin stimulatory response to clomiphene: Case report. J. Clin. Endocrinol. Metab., 33: 551 (1971).

8. Loriaux, D. L., Ruder, H. J., and Lipsett, M. B.: The measurement of estrone sulfate in plasma. Steroids, 18: 463 (1971).

9. Monroe, S. E., Jaffe, R. B., and Midgley, A. R., Jr.: Regulation of human gonadotropins. XII. Increase in serum gonadotropins in response to estradiol. J. Clin. Endocrinol., 34: 342 (1'972)

10. Odell, W. D., Rayford, P. L., and Ross, G. T.: Simplified partially automated method for radioimmunoassay of human thyroid stimulating, growth, luteinizing, and follicle stimulating hormones. J. Lab. Clin. Med., 70:973 (1967)

11. Reiter, E. O., Kulin, H. E., and Hamwood, S. M.: The absence of positive feedback between estrogen and luteinizing hormone in sexually immature girls. Pediat. Res., 8: 740 (1974).

12. Roth, J. C., Kelch, R. P., Kaplan, S. L., and Grumbach, M. M.: FSH and LH response to luteinizing hormone-releasing factor in prepubertal and pubertal children, adult males and patients with hypogonadotropic and hypergonadotropic hypogonadism. J. Clin. Endocrinol. Metab., 35: 926 (1972)

13. Santen, R. J.: Is aromatization of testosterone to estradiol required for LH suppression in men? J. Clin. Invest. Suppl. (1975)

14. Santen, R. J., Leonard, J. M., Sherins, R. J., Gandy, H. M., and Paulsen, C. A.: Short- and long-term effects of clomiphene citrate in the pituitary-testicular axis. J. Clin. Endocrinol., 33: 970 (1971).

15. Seyler, L. E., Jr., and Reichlin, S.: Feedback regulation of circulating LRF concentrations in men. J. Clin. Endocrinol. Metab., 39: 906 (1974).

16. Siegel, S.: Nonparametric statistics for the behavioral sciences, Chapt. 6 (McGraw-Hill Book Co., New York, 1956).

17. Stearns, E. L., Winter, J. S. D., and Faiman, C.: Positive feedback effect of progestin upon serum gonadotropins in estrogen-primed castrate men. J. Clin. Endocrinol. Metab., 37: 635 (1973).

18. Yamaji, T., Dierschke, D. J., Hotchkiss, J., Bhattacharya, A. N., Surve, A. H. and Knobil, E.: Estrogen induction of $\mathrm{LH}$ release in the rhesus monkey. Endocrinology, 89: 1034 (1971).

19. Yen, S. S. C., Tsai, C. C., Vandenberg, G., and Rebar, R.: Gonadotropin dynamics in patients with gonadal dysgenesis: A model for the study of gonadotropin regulation. J. Clin. Endocrinol. Metab., 35: 897 (1972).

20. Progynon (either as the aqueous suspension or solution in oil), Schering Corporation, Bloomfield, N. J.

21. Subsequent to the study, the 13-year-old prepubertal boy entered an apparently normal puberty. 
22. Thanks are due to Mr. James Brice for technical assistance and to Mrs. Evelyn Lewis for aid in preparing the manuscript.

23. This paper was presented in part at the National Institutes of Health Symposium on The Control of the Onset of Puberty, Airlie House, Virginia, October, 1972, and at the Fourteenth International Congress of Pediatrics, Buenos Aires, October, 1974.

24. The present address of Dr. H. E. Kulin is: Department of Pediatrics, The Milton S. Hershey Medical Center, The Pennsylvania State University, College of
Medicine, Hershey, Pa. 17033

25. The present address of Dr. E. O. Reiter is: Department of Pediatrics and The Ed Wright Pediatric Endocrine Laboratory, The University of South Florida College of Medicine, All Children's Hospital, St. Petersburg, Fla. 33701.

26. Requests for reprints should be addressed to: H. E. Kulin, M.D., Department of

Pediatrics, The Milton S. Hershey Medical Center, The Pennsylvania State University, College of Medicine, Hershey, Pa. 17033 (USA).

27. Accepted for publication September 3, 1975.

Pediat. Res. 10:51-56 (1976)

Galactose glucose

glycogen insulin liver newborn

\title{
Glycogen Regulation in Isolated Perfused Near Term Monkey Liver
}

\author{
JOHN W. SPARKS, ${ }^{(30)}$ ALMORRIS LYNCH, RONALD A. CHEZ, AND WALTER H. GLINSMANN \\ Section on Physiological Controls, Laboratory of Biomedical Sciences and Pregnancy Research Branch, National \\ Institute of Child Health and Human Development, National Institutes of Health, Bethesda, Maryland, USA
}

\section{Extract}

Glycogen metabolism was studied in the isolated perfused liver of the monkey conceptus at $90 \%$ of gestation using an in situ recirculating perfusion system. Net uptake of glucose and galactose and the activities of the enzymes, glycogen synthetase and phosphorylase, were studied in response to varied perfusate composition. Synthetase activity was expressed as $\% \mathbf{I}$, the percentage of total synthetase activity in the active form. Perfusate glucose concentrations as high as $700 \mathrm{mg} / 100 \mathrm{ml}$ did not lead to net glucose uptake or to an increase in the baseline $\%$ I synthetase $(4 \pm 1$, mean \pm SEM $)$. In the presence of $300 \mathrm{mg} / 100 \mathrm{ml}$ glucose, insulin at $10^{-7} \mathrm{M}$ increased $\% \mathrm{I}$ to $8 \pm 2$, and galactose $>75 \mathrm{mg} / 100 \mathrm{ml}$ increased $\% I$ to $8 \pm 1$. The combination of galactose, glucose, and insulin increased $\%$ I to $40 \pm 5$. With this latter combination, synthetase activity was proportional to perfusate glucose concentration above $100 \mathrm{mg} / 100 \mathrm{ml}$. Phosphorylase activity was diminished by either galactose or insulin, and phosphorylase activity was lowest in the group receiving galactose, glucose, and insulin. Galactose was taken up by all livers, but net glucose uptake was not observed under any condition; net hexose uptake was observed in perfusions with galactose. Glycogen levels did not vary significantly with varied perfusate composition during the 30 -min perfusion periods.

\section{Speculation}

We speculate that galactose may be uniquely important for neonatal liver glycogen synthesis, and that its action is mediated through reciprocal changes in the activities of the enzymes, glycogen synthetase and phosphorylase. If liver glycogen is important for acute neonatal glucose homeostasis, then galactose may also be essential for maintaining circulating glucose concentration by ensuring glycogen synthesis during feeding.

The infant has a continuing obligatory requirement for glucose $(7,23)$. During feeding, this requirement is met by exogenous glucose, the excess carbohydrate being stored principally as glycogen. During fasting, the liver derives glucose both from gluconeogenesis and from mobilization of stored carbohydrate, principally liver glycogen $(1,23)$. Since gluconeongenesis is limited in the infant $(1,15)$, liver glycogen synthesis and mobilization may be particularly important for maintaining circulating glucose levels.

Glycogen metabolism in liver is regulated by reciprocal changes in the activities of the rate-limiting enzymes of glycogen synthesis and degradation, glycogen synthetase and glycogen phosphorylase, respectively. The isolated adult rat liver regulates the activities of these two enzymes directly in response to circulating glucose concentration as well as in response to hormones $(4,12,13,20)$. The relative physiologic contributions of glucose and hormonal regulation of glycogen metabolism in vivo are unknown.

In a previous study with isolated, perfused newborn monkey liver (11), we provided evidence that glucose mobilization occurred in response to hypoglycemia or glucagon. However, net glucose uptake and activation of glycogen synthetase did not occur in response to hyperglycemia. This lack of response to hyperglycemia suggested to us that the infant primate liver may be limited in its ability to store glucose as glycogen in the presence of hyperglycemia, such as might occur in the portal vein during feeding. We also considered the possibility that other dietary constituents might regulate glycogen synthesis directly.

In an companion study (28), we have provided evidence that galactose as well as glucose regulates glycogen cycle enzyme activities and promotes glycogen synthesis in the isolated perfused liver of the adult rat. Galactose and glucose form lactose, the principal dietary carbohydrate in milk (6). In human milk, lactose provides $40 \%$ of the total calories (19). Galactose-metabolizing enzymes are well developed at birth (6). Because of the abundance of galactose in the newborn period, and the known enzymatic pathways !inking galactose, glucose, and glycogen metabolism, we questioned whether galactose might play a major role in glycogen metabolism of the newborn primate liver.

In the present study we provide evidence that the isolated perfused liver of the near term monkey regulates glycogen enzyme activities in response to a combination of galactose, glucose, and insulin. We speculate that galactose may play a unique role in glycogen synthesis during the newborn period. 